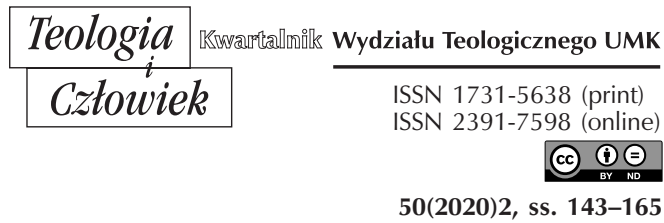

KS. KAZIMIERZ STANISŁAW SKOCZYLAS

UNIWERSYTET MIKOŁAJA KOPERNIKA W TORUNIU

KAZIMIERZ.SKOCZYLAS@UMK.PL

ORCID 0000-0002-3287-5317

\title{
STOSUNEK TEOLOGÓW KATOLICKICH W POLSCE DO WYCHOWANIA PAŃSTWOWEGO PRZED II WOJNĄ ŚWIATOWA
}

DOI: http://dx.doi.org/10.12775/TiCz.2020.022

Streszczenie. Środowisko teologów katolickich w Polsce w okresie 1920-1939 aktywnie uczestniczyło w przemianach dokonujących się w Polsce okresu międzywojennego. Była to przede wszystkim aktywność intelektualna przejawiająca się w licznych publikacjach naukowych. Oprócz problematyki teologicznej podejmowało też krytyczną refleksję odnoszącą się do koncepcji wychowania w Rzeczypospolitej. Przedmiotem ich zainteresowania i krytycznej oceny były również propozycje wychowania szkolnego. Ówczesne państwo polskie zamieszkiwali obywatele wielu narodowości. W latach 30 . XX wieku władze przyjęły koncepcję wychowania w duchu państwowym, pomagającym integrować tak zróżnicowaną ludność wokół służby dla państwa. Przedstawiciele środowiska teologów katolickich krytycznie oceniali przyjęte koncepcje w duchu pedagogiki katolickiej oraz podkreślali potrzebę wychowania w duchu katolickim, opierając się na postanowieniach konkordatu między Stolicą Apostolską a Rzeczpospolitą Polską.

Słowa klucze: pedagogika; wychowanie; wychowanie narodowe; wychowanie państwowe; wychowanie religijne.

Abstract. The attitude of Catholic theologians in Poland to state education before the Second World War. The Catholic theologians in Poland in the period 1920-1939 actively participated in the transformations taking place in Poland in the interwar 
period. It was mainly intellectual activity manifested in numerous scientific publications in the field of theology. In addition to theological issues, they also undertook a critical reflection regarding the concept of education in the Republic of Poland. The issue of school education was also the subject of their interest and critical assessment. The Republic of Poland of that time was inhabited by citizens of many nationalities. In the 1930s, the authorities adopted the concept of upbringing in a state spirit that would help integrate such a diverse population around the act of serving to the state. Representatives of the Catholic theologians were critical of the ideas adopted in the spirit of Catholic pedagogy and emphasized the need for education in the Catholic spirit based on the provisions of the concordat between the Holy See and the Republic of Poland.

Keywords: pedagogy; education; national education; state education; religious education.

Polskie środowisko katolickich teologów w okresie międzywojennym miało swoją reprezentację. Teologowie pracujący na wydziałach teologicznych w uniwersytetach, jak i ci, którzy wykonywali swoje obwiązki, ucząc w seminariach duchownych, byli zrzeszeni w Związku Zakładów Teologicznych im. św. Jana Kantego. Ten związek został powołany za aprobatą biskupów polskich w 1921 roku. Jego działania przyczyniły się do intensyfikacji poszukiwań teologicznych w Polsce. Ważną formą rozwoju tego środowiska i wymiany myśli były kongresy. W okresie międzywojennym zwołano osiem kongresów. Inspirowały one rozwój badań teologicznych prowadzonych $\mathrm{w}$ ramach wielu sekcji. W tamtym okresie działały między innymi sekcja teologii dogmatyczno-apologetycznej, moralnej, prawa kanonicznego, Pisma Świętego, duchowości, teologii praktycznej, katechetyki i pedagogiki, historii Kościoła, homiletyczno-patrologiczna, liturgiczna, historii sztuki i filozoficzna ${ }^{1}$. Działalność tego środowiska znajdowała wyraz w publikacjach zamieszczanych na łamach polskich czasopism teologicznych, w samodzielnych publikacjach, jak również w tłumaczeniu wartościowych dzieł teologicznych na język polski². Od czwartego zjazdu Związku Zakładów Teologicznych, który odbył się w 1927 roku w Kielcach, organem prasowym tego związku stało się

1 Por. K. Skoczylas, Związek Zakładów Teologicznych im św. Jana Kantego w Polsce, „Studia Włocławskie” 20 (2018), s. 30-32.

2 Tamże, s. 32-37. 
„Ateneum Kapłańskie”. Stąd na jego łamach z tamtego okresu znaleźć można wiele artykułów podejmujących aktualną wówczas problematykę. Wiele uwagi poświęcono $\mathrm{w}$ artykułach problematyce wychowania.

Problematyka wychowania była szczególnie istotna w Polsce. Polska odzyskała niepodległość w 1918 roku. Powstałe państwo składało się z terenów należących przez 123 lata do trzech różnych zaborów. Elementy kultury i tradycji krajów zaborczych odcisnęły na mieszkańcach ziem przynależących do zaborców silne piętno. Stąd nowe państwo musiało zmagać się z wieloma trudnościami wynikającymi z tej przynależności. Ponadto Polska po 1918 roku była krajem wielonarodowym. Funkcjonowanie państwa $\mathrm{z}$ wieloma mniejszościami narodowymi rodziło różne trudności. Również stawiano sobie pytania dotyczące koncepcji wychowania nowych pokoleń. Stopniowo dojrzewała myśl, aby ideę wychowania narodowego zastąpić ideą wychowania państwowego. Do realizacji idei wychowania państwowego przyczyniła się reforma jędrzejewiczowska z 1933 roku. Wprowadzała ona w całym systemie szkolnym Polski koncepcję wychowania państwowego.

Zamiar wprowadzenia wychowania państwowego do polskiego systemu szkolnego rozbudził dużą dyskusję na temat wizji wychowania w Polsce ${ }^{4}$. To rodziło też różne obawy i zastrzeżenia w środowisku katolickim. Wyrażali je także członkowie Związku Zakładów Teologicznych na łamach „Ateneum Kapłańskiego”. Ich wypowiedzi kształtowały opinię środowisk katolickich w całej Polsce. Stąd warto poznać ich poglądy.

\section{ROZWÓJ KONCEPCJI WYCHOWANIA W POLSCE W OKRESIE MIĘDZYWOJENNYM}

Problematyka wychowania międzywojennego jest silnie zakotwiczona w okresie poprzedzającym odzyskanie przez Polskę niepodległości. Tereny polskie w okresie zaborów poddane były polityce zaborców dążących do wynarodowienia Polaków. Reakcją na to była stopniowo rozwijająca się polska kultura narodowa, która szczególnie intensywnie rozwijała

3 Tamże, s. 33-34.

4 Por. Z. Mysłakowski, Wychowanie państwowe a narodowe, Lwów-Warszawa 1931; I. Panenkowa, Wychowanie państwowe czy narodowe, Warszawa 1930. 
się w wieku XIX. Promowała ona wychowanie nowych pokoleń w duchu narodowym. Ten trend zaznaczył się między innymi przez uczestnictwo wielu polskich środowisk w wiośnie ludów, w powstaniach listopadowym i styczniowym. Do umocnienia się polskiej kultury narodowej przyczyniły się liczne publikacje literackie. W duchu narodowym tworzyli: Józef Ignacy Kraszewski, Adam Mickiewicz, Juliusz Słowacki, Eliza Orzeszkowa czy Maria Konopnicka. Nie można pominąć też twórczości plastycznej choćby Jana Matejki czy twórczości muzycznej między innymi Fryderyka Chopina oraz Stanisława Moniuszko. Upowszechnianiu się tej kultury sprzyjała polska prasa ${ }^{5} \mathrm{i}$ inne wydawnictwa literackie. Wartości narodowe były także obecne w życiu polskich rodzin ${ }^{6}$.

\subsection{WYCHOWANIE NARODOWE}

Pedagodzy odegrali znaczącą rolę w sformułowaniu naczelnych idei wychowania w duchu narodowym. Do pedagogów zajmujących się ideologią tego wychowania zalicza się Stanisława Prus-Szczepanowskiego. Był on przekonany, że naród polski ma specjalną misję, a pedagogika narodowa ma do niej przygotować ${ }^{7}$. Uważał on, że warunkiem jej realizacji jest praca nad przemianą moralną, która doprowadzi do duchowego odrodzenia i odzyskania wolności. W wychowaniu tym trzeba kierować się zasadami, do których przywiązani są Polacy, a zwłaszcza przywiązaniem do tradycji, do bohaterów narodowych czy konkretnych wzorów postępowania ${ }^{8}$. Ideologię tę rozwijał dalej Zygmunt Balicki. Podkreślał on, że naród stanowi najwyższą społeczność zbiorową, w której jednostka się rodzi. Wychodząc z tego założenia, chciał, aby zarówno teoria, jak i praktyka pedagogiczna były przeniknięte duchem narodowej myśli. Podstawowym zadaniem narodowym jest wdrażanie młodzieży do takiego wychowania,

5 Powszechnie czytane były między innymi „Gazeta Świąteczna” założona przez K. Pruszyńskiego w Warszawie w 1881 r., gazety promowane w Wielkopolsce przez Towarzystwo Czytelni Ludowych, prasa wydawana przez Towarzystwo Popierania przemysłu i Handlu Polskiego wydające m.in. „Gazetę Niedzielną” i inne.

${ }^{6}$ L. Dyczewski, Rodzina twórca i przekazicielem kultury, Lublin 2003.

7 S. Szczepanowski, Myśli o odrodzeniu narodowym, Lwów Warszawa 1923.

8 Tenże, O polskich tradycjach wychowawczych, Lwów 1912, s. 250-281. 
aby mogła poczuć jedność z Ojczyzną ${ }^{9}$ W tym wychowaniu podkreślał konieczność poznania dziejów ojczystych, a przez to pokochania ziemi i ludzi ją zamieszkujących. Drugim wymiarem jego koncepcji było wychowanie obywatelskie, które miało wykreować typ żołnierza obywatela. Przypisywał on też szczególną rolę religii katolickiej będącej źródłem życia duchowego ${ }^{10}$.

Ukształtowany ideał wychowania narodowego był poddany weryfikacji w okresie po powstaniu państwa polskiego. Próby jego realizacji podejmowała narodowa demokracja. Współpracujący z tą formacją polityczną pedagodzy zauważyli nieadekwatność niektórych elementów ideału wychowania narodowego. Rozumiano, że ten ideał wychowania musi mocno łączyć się ze szkołą będącą narzędziem urabiania społeczeństwa. Zaczęto bardziej rozumieć, że cele wychowania i ideały wychowawcze powinny być zharmonizowane $\mathrm{z}$ systemem szkolnictwa i treściami nauczania. Rozpoczęto badania pedagogiczne nad celami wychowania, koncepcjami dydaktycznymi i ustrojowymi. Sugerowano, by ideał Polaka obywatela zastąpić między innymi ideałem obywatela robotnika, który całym sercem powinien służy Polsce ${ }^{11}$. Dostosowanie ideałów wychowania narodowego do współczesnej szkoły z ramienia endecji podjął minister oświaty Stanisław Grabski. Jednak projekt reformy przez niego przedstawiony wywołał wielkie poruszenie i opór środowisk nauczycielskich oraz opozycyjnych partii oraz szeroko prowadzonej publicystyki. W koncepcjach tych zabrakło wyeksponowania ideałów wychowawczych połączonych z praktyczną realizacją w szkolnictwie. Choć w okresie niewoli eksponowano wiele cech tego ideału, jak pełen rozwój osobowości z przygotowaniem do pełnienia misji narodowej, do której prowadzić miało odrodzenie narodowe. W wykształceniu prowadzącym do niego doceniano znaczenie nauk matematyczno-przyrodniczych. Szczepanowski akcentował też zaangażowanie ideowe wychowanków i ich złączenie wokół wspólnego celu, jakim miało być dobro narodu. Wychowanie powinno łączyć integralnie elementy emocjonalne, intelektualne z kształtowaniem

9 Z. Balicki, Zasady wychowania narodowego, Warszawa 1909 s. 3-4

10 Tamże, s. 14.

11 Por. J. Sobczak, Przykłady formułowania ideału Obywatela-Patrioty na tle istotnych dla narodu polskiego wydarzeń polityczno-społecznych, "Studia Pedagogiczne” 1980, z. 6, s. $28-34$. 
charakteru. Podkreślano takie cechy, jak punktualność, dokładność, karność ${ }^{12}$. Balicki akcentował przepojenie wychowania duchem narodowym, przez co rozumiał wprowadzenie młodzieży w tradycje narodowe, dawanie podstaw pozytywnego patriotyzmu, wychowanie polskiego żołnierza obywatela. On przed kształceniem stawiał wychowanie oparte na religii i wychowaniu fizycznym. Wynikiem takiego wychowania miała być zdolność wychowanka do współdziałania z innymi, karność, koleżeństwo, solidarność, aktywność, odporność na nieodpowiedzialny humanitaryzm $^{13}$. Niektóre elementy jego koncepcji wychowawczej zawierały także elementy nacjonalizmu ${ }^{14}$. Koncepcję wychowania narodowego starał się unowocześnić L. Zarzecki. Proces wychowania starał się rozumieć nie tyle jako przekazywanie doświadczeń, ile jako tworzenie nowych wartości i budzenie geniuszu narodowego. Ideałem moralnym dla Zarzeckiego było wartościowanie, w którym stawia się wyżej interes narodowy niż dobro własne, czy też dobro poszczególnych grup i klas. Podstawę wychowania widział w wychowaniu religijnym ${ }^{15}$. Roman Dmowski do zarysowanego ideału dodał konieczność zwalczania cech negatywnych ${ }^{16}$. Tę koncepcję wychowania starano się wprowadzić do szkól w latach 1919-1922. Jednak endecy nie byli przygotowani do wprowadzenia tej ideologii w praktykę życia szkolnego. Nie byli w stanie ogólnych idei powiązać z treścią kształcenia i poprzeć konkretnym materiałem dydaktycznym. Niektórzy badacze tego okresu twierdzą, że endecja nie miała dostatecznej siły politycznej ani wpływów wśród pedagogów, którzy przygotowywali projekty ustrojowe, a potem programy szkolne. Nauka szkolna według tych koncepcji nie była w stanie przekształcić mentalności nowych pokoleń. Koncepcje tego wychowania cechowały się nastawieniem elitarnym, ukierunkowaniem na wychowanie inteligencji. Tymczasem coraz bardziej dochodziły do głosu tendencje demokratyczne domagające się powszechnego dostę-

12 Por. S. Szczepanowski, Myśli o wychowaniu, Lwów 109,

${ }_{13}$ Por. Z. Balicki, Egoizm narodowy wobec etyki, Lwów 1903; tenże, Zasady wychowania narodowego.

${ }^{14}$ Por. K. Bartnicka, Wychowanie państwowe: do dyskusji nad problemami ideologii wychowawczej sanacji, „Rozprawy z Dziejów Wychowania” 12 (1972), s. 68.

15 Por. L. Zarzecki, Wychowanie narodowe, Warszawa 1929.

${ }_{16}$ Por. M. Szepietowski, Naród i wychowanie w myśli Romana Dmowskiego, „Niepodległość i Pamięćc12 (2005) nr 1, s. 149-152. 
pu do wykształcenia dla całego społeczeństwa. Stąd coraz silniejszy był opór wobec prób realizacji wychowania narodowego. Ostatnią batalię o wprowadzenie wychowania narodowego podjął minister wychowania S. Grabski w 1925 roku. Koncepcja jego budziła sprzeciw wśród różnych grup i związków nauczycieli, jak i u przeciwników politycznych. Opór był tak silny, że przygotowany przez niego projekt został wycofany spod obrad sejmu w 1926 roku $^{17}$. Odtąd koncepcja wychowania narodowego jest w odwrocie. Natomiast promuje się od tej pory koncepcję wychowania państwowego związaną z obozem sanacyjnym.

\subsection{WYCHOWANIE PAŃSTWOWE}

Wychowanie państwowe było koncepcją przygotowaną i realizowaną przez obóz sanacyjny w Polsce po zamachu majowym w 1926 roku do 1939 roku. Można wskazać trzy istotne etapy w jego realizacji. Pierwszym etapem jest budowanie jego koncepcji oraz precyzowanie jego ideału, następnym momentem jest reforma szkolnictwa nazywana reformą jędrzejewiczowską, która rozpoczęła się w roku 1932, oraz etap wcielania w życie tego wychowania trwający do wybuchu II wojny światowej. Wartości istotne dla tej koncepcji wychowania były analizowane $\mathrm{w}$ środowisku intelektualnym i pedagogicznym, a kolejni ministrowie Ministerstwa Wyznań Religijnych i Oświecenia Publicznego podejmowali działania prowadzące do jego urzeczywistnienia.

Kolejnym etapem było przygotowanie wizji tego wychowania. Rozpoczęły je wystąpienia ministra WRiOP Sławomira Czerwińskiego w 1929 roku na zjazdach inspektorów oświaty w Poznaniu, Warszawie i Wilnie określające ideał wychowania państwowego. W swojej wypowiedzi podkreślił, że wiele aspektów ideału wychowawczego przejęto z okresu niewoli. Zaliczył tu przede wszystkim ideał poddania się bardziej znaczącemu oraz przywiązanie do formalizmu, do zgodności z literą prawa, a często brakiem osobistych relacji wychowawcy z wychowankiem. Kreśląc zręby nowego ideału, odwołuje się do tradycji narodowej. W niej odnajduje dwa najczęstsze typy psychiczne: bojownika i pracownika. Każdy z nich ma

\footnotetext{
17 K. Bartnicka, Wychowanie państwowe, s. 61-72.
} 
zarówno cechy pozytywne, jak i cechy negatywne. W czasie budowania własnej państwowości potrzebne są pozytywne cechy obu tych typów psychicznych bojownika i pracownika. Nowy typ obywatela powinien być wytrwały w pracy i mieć odwagę podejmować nowe wyzwania ${ }^{18}$. Minister Czerwiński podkreślił też, że w Polsce, która jest krajem wielonarodowym, potrzebny jest jeden ideał wychowania państwowego, wokół którego mogą się skupić wysiłki wychowawcze różnych nacji zamieszkujących teren Polski. Słuszność takiego wychowania, jego zdaniem, potwierdzają zjawiska obserwowane w ówczesnym harcerstwie, gdzie jedni widzą potrzebę harcerstwa ukraińskiego, inni czerwonego, a jeszcze inni akcentują jeszcze inny obszar wartości. Jego zdaniem wieloletnie wychowanie w takim duchu może być przyczyną bardzo intensywnych konfliktów. Stąd rząd musi podejmować wysiłki scalające proces wychowania w duchu państwowym i obywatelskim ${ }^{19}$. W trakcie wystąpienia sejmowego minister Czerwiński w dniu 10 lutego 1931 roku określił, czym jest wychowanie państwowe. Powiedział wówczas „Rozumiemy przez nie takie zorganizowanie i takie nastawienie pracy $\mathrm{w}$ instytucjach wychowania publicznego, aby rezultatem tego wychowania był obywatel przygotowany fizycznie, umysłowo, a zwłaszcza moralnie do ofiarnej służby dla państwa" ${ }^{20}$. Nieco dalej mówił „[...] cel, który stawiamy, jest zgodny z najistotniejszymi potrzebami narodu, który, po długiej niewoli odzyskawszy wolność powinienby wszystko uczynić, aby tę wolność utrwalić i zabezpieczyć" 21 , a po tym dodał „Zdajemy sobie sprawę z tego, że wobec sfery zagadnień, w jakich dotychczas głównie obracała się szkoła polska, hasło wychowania obywatelsko-państwowego nie natychmiast i nie wszędzie liczyć może na pełne zrozumienie. Nie chcemy go forsować wyłącznie przymusem; przeciwnie, pragniemy, aby zasady realizacji tego hasła były rezultatem zbiorowego wysiłku możliwie szerokich sfer nauczycielstwa"22.

W tym samym czasie, w 1929 roku ministerstwo oświaty rozpoczęło szereg kursów dla dyrektorów i nauczycieli. To pozwoliło spopularyzo-

\footnotetext{
18 S. Czerwiński, O nowy ideał wychowawczy, Warszawa 1934, s. 22-39.

19 Tamże, s. 40-55.

20 Tamże, s. 77.

21 Tamże, s. 78.

22 Tamże, s. 79.
} 
wać idee tego wychowania i pozyskać wielu nauczycieli dla tej koncepcji. Ministerstwo wzmacniało oddziaływanie na środowisko nauczycielskie przez wydawanie czasopism dla nauczycieli. Jednym z nich było „Oświata i Wychowanie”23. Dalszym krokiem było nawiązanie kontaktów z przywódcami organizacji nauczycielskich (ZPNSP oraz ZZNZSŚ) grupujących nauczycieli szkół powszechnych i średnich. Te organizacje udzieliły poparcia tej idei wychowania ${ }^{24}$.

Ważnym środowiskiem przygotowującym to wychowanie było środowisko współpracujące z czasopismem „Zrąb”. Jego redaktorem naczelnym był przez pierwszy okres Janusz Jędrzejewicz. Celem „Zrębu” było nawiązanie łączności pomiędzy władzami oświatowymi a pracownikami oświaty i całym społeczeństwem. Ujawniało się dążenie władz sanacyjnych do objęcia akcją wychowania państwowego całego społeczeństwa. Przez działalność „Zrębu” władza chciała stworzyć jednolity front społeczny wobec oświaty i wychowania ${ }^{25}$. Na jego łamach popularyzowano również ideę wychowania państwowego ${ }^{26}$. Tam tę ideę popularyzował sam Janusz Jędrzejewicz. Uwypuklał, że państwo jest dobrem wspólnym i najwyższą formą organizacji społeczeństwa. Dlatego trzeba wychować do dbałości o dobro wspólne do jego pomnażania. To zaś oznaczało kształtowanie pozytywnego zaangażowania do udziału w życiu państwowym ${ }^{27}$. Inni autorzy analizowali relacje wychowania państwowego do treści wielu przedmiotów szkolnych ${ }^{28}$.

Po śmierci ministra Czerwińskiego w sierpniu 1931 roku szefem Ministerstwa Wyznań i Oświecenia Publicznego został Janusz Jędrzejewicz. Odtąd nastąpiła intensyfikacja działań zmierzających do zreformowania polskiej szkoły. Ówczesna polityka oświatowa zmierzała do uwy-

${ }^{23}$ K. Bartnicka, Wychowanie państwowe, s. 79.

24 Tamże, s. 80.

25 Por. „Zrąb” 1930, nr 1, s. 3-5.

${ }^{26}$ Por. J. Jędrzejewicz, Wychowanie państwowe, „Zrąb” 1930, nr 3, s. 311-320.

27 Tamże, s. 314-320.

${ }^{28}$ Por. T. Wałek Czarnecki, Kultura klasyczna a wychowanie państwowe, „Zrąb” 1930, nr 3, s. 348-359; S. Arnold, Teoretyczne podstawy nauki o Polsce wspótczesnej, „Zrąb” 1930, nr 3, s. 334-347; A. Patkowski, Poznanie własnej ziemi jako podstawa wychowania obywatelskiego, „Zrąb” 1930, nr 3, s. 370-377. 
puklenia w świadomości zbiorowej faktu istnienia niepodległej Polski ${ }^{29}$. Prace twórców reformy oświatowej były nastawione na zapewnienie jak największej skuteczności podejmowanym działaniom. W programach szkolnych starano się treści projektowanej reformy powiązać z okresami rozwojowymi i dostosować je do możliwości rozwojowych wychowanków. Dążenie do przygotowania integralnego systemu wychowawczego wspierane było przez działania ministerstwa wśród nauczycieli. Starano się w wychowaniu państwowym przedstawiać wzór osobowy zaangażowania w sprawy budowy i ochrony państwa. Stąd środowisko sanacyjne skupione wokół Ministerstwa Wyznań i Oświecenia Publicznego promowało osobę Józefa Piłsudskiego jako doskonały wzór osobowy. To zaś spotykało się $\mathrm{w}$ wielu ówczesnych środowiskach $\mathrm{z}$ niechęcią ${ }^{30}$. Jednak krytyczna ocena przedstawionych rozwiązań płynąca z opozycyjnych środowisk uwypukliła słabości tej koncepcji. Do jego słabości należały między innymi niedopracowanie samego pojęcia wychowania państwowego i koncepcji tego wychowania. To zaś przysparzało sanacji wielu problemów. Stwarzało bowiem wiele możliwości interpretacji tej koncepcji, sprzecznych z intencjami projektodawców ${ }^{31}$.

Efektem wyżej wskazanych prac była ustawa sejmowa. Długo przygotowywaną ustawę o ustroju szkolnictwa przedstawiono w Sejmie w dniu 11 marca 1932 roku. Ustawa została przez sejm przyjęta. Wprowadzała ona jednolity ustrój szkolny na terenie całej Polski. Uwypukliła wychowawczy charakter szkoły w duchu wychowania państwowego. Podstawą systemu szkolnego była siedmioklasowa szkoła powszechna. Przewidziano dla niej trzy stopnie zorganizowania. Pierwszy stopień organizacyjny obejmował elementarny zakres wykształcenia. Jego realizacja wymaga przekazania treści z pierwszego szczebla organizacyjnego i najważniejszych treści ze szczebla drugiego. Drugi stopień organizacyjny realizować miał treści ze szczebla pierwszego i drugiego z najważniejszymi treściami szczebla trzeciego. Szkoła trzeciego stopnia organizacyj-

${ }^{29}$ M. Stolarczyk, Wychowanie państwowe w Drugiej Rzeczypospolitej w świetle programów szkolnych (po wprowadzeniu reformy oświatowej z 1932 roku, „Lubelski Rocznik Pedagogiczny" 37 (2018), z. 3, s. 215-235.

${ }^{30}$ Por. B. Topij-Stempińska, P. Kaźmierczak, Wychowanie narodowe a wychowanie państwowe, „Horyzonty Wychowania” 7 (2008) nr 14, s. 225-239.

31 K. Bartnicka, Wychowanie państwowe, s. 95-98. 
nego miała realizować program 7-letni w następujący sposób, że cztery pierwsze lata przeznaczano na szczebel pierwszy, dwa następne lata na szczebel drugi, a na szczebel trzeci ostatni rok. Jeśli szkoła była 8-letnia, to trzeci szczebel realizowano dwa lata. Ważne było zaakcentowanie zasadniczego celu szkoły powszechnej. Miała ona dać odpowiednie wiekowi i rozwojowi dziecka potrzebne ogółowi obywateli wykształcenie ogólne oraz wychowanie obywatelsko-społeczne ${ }^{32}$. Ustawa stworzyła jednolity ustrój organizacyjny szkolnictwa, ponieważ oprócz szkoły powszechnej wprowadzała szkołę średnią ogólnokształcącą składającą się z czteroletniego gimnazjum i dwuletniego liceum. Wprowadzała też szkolnictwo zawodowe. Określiła drogę kształcenia nauczycieli dla przedszkoli i szkół powszechnych. Ustawa przyniosła wiele skutków pozytywnych. Pierwszym było uporządkowanie na terenie całej Polski jednolitego ustroju szkolnego. Ona też zreformowała system kształcenia nauczycieli, wydłużając okres kształcenia i stawiając kandydatom wyższe wymagania. Dzięki niej wszyscy absolwenci liceów mogli podejmować studia, co oznaczało znaczne rozszerzenie spektrum społecznego wśród studiujących. Wadą przeprowadzonej reformy systemu szkolnictwa był brak drożności w systemie kształcenia. Powszechnie krytykowano ją za to, że uczniowie kończący szkołę powszechną pierwszego szczebla organizacyjnego pozbawieni byli możliwości kontynuowania nauki w szkole średniej. Tych uczniów na terenie Rzeczypospolitej w tamtym okresie było najwięcej ${ }^{33}$.

Popularyzacji wychowania państwowego poświęcono sporo publikacji ${ }^{34}$. Ale trzeba zauważyć, że na płaszczyźnie naukowej, a przede wszystkim w pedagogice istotny wkład miała też publikacja Kazimierza Sośnickiego. Była to jego praca habilitacyjna opublikowana w 1936 roku pt. Podstawy wychowania państwowego ${ }^{35}$. Autor podkreśla, że relacje międzyludzkie w społeczeństwie charakteryzują kolizje, czyli sprzecz-

32 Por. Ustawa z dnia 11 marca 1932 roku o ustroju szkolnictwa, Dz.U. 1932 Nr 38 poz. 398 , art. $5-12$.

${ }^{33}$ Por. W. Grabowska, Jędrzejewiczowska ustawa szkolna $z 1932$ roku, „Rozprawy z Dziejów Wychowania” 12 (1969), s. 123-141.

${ }^{34}$ Por. I. Pannenkowa, Co to jest wychowanie państwowe, Warszawa 1932; M. Ziemnowicz, Rodzina a wychowanie państwowe, Warszawa-Lwów 1932; M. Ziemnowicz, Wychowanie państwowe w szkole, „Przegląd Pedagogiczny” 1931, nr 15-16, s. 13-23.

35 Por. K. Sośnicki, Podstawy wychowania państwowego, Lwów-Warszawa 1936. 
ności interesów grup i jednostek. Wychowanie natomiast może pomóc zapanować nad tymi kolizjami. Państwo może regulować kolizje poprzez nakazy i zakazy, czyli stanowienie prawa. Ale to często jest mało skuteczne. O wiele bardziej dobre rezultaty w przezwyciężaniu ich przynosi wychowanie. Wartość człowieka w stosunku do zbiorowości zależy od treści zasad, którymi się kieruje w rozwiązywaniu kolizji i od siły, jaką im potrafi nadać, gdy realizuje je w praktyce. Przyswojenie tych zasad jest efektem wychowania. Celem wychowania będzie przyswojenie tych zasad. Wychowanie to powinno opierać się na etosie funkcjonującym w społeczeństwie. Etos zaś to zbiór zasad, które kierują powstaniem, przebiegiem i rozwiązywaniem kolizji. Etos składa się, zdaniem Sośnickiego, z zakazów przeciw negatywnym czynnikom rozbijającym łączność między ludźmi oraz elementów pozytywnych pogłębiających łączność między ludźmi ${ }^{36}$. Zasady obecne w etosie mają charakter norm, których celem jest ochrona istotnych wartości ${ }^{37}$. W społeczeństwie funkcjonuje etos różnych grup społecznych, który może być zbieżny albo przeciwstawny. Szczególne znaczenie w społeczeństwie ma państwo i jego etos. Etos państwowy charakteryzuje się trwałością, dążeniem do jego utrzymania bez zmiany. Trwałość etosu państwowego leży w woli państwa do zachowania go $\mathrm{w}$ pewnej ustalonej formie. Trwanie tego etosu leży też w interesie jego obywateli, bo on umożliwia im jednolity i uporządkowany styl życia. Etos państwowy charakteryzuje się, zdaniem K. Sośnickiego, wyłącznością. Na terytorium jednego państwa jest on czynnikiem władczym podporządkowującym sobie etos moralny i etosy grupowe. Dzięki tym właściwościom etos państwowy staje się najintensywniejszym czynnikiem wychowawczym ${ }^{38}$.

Wychowanie państwowe polega na głębokim wbudowaniu tego etosu w strukturę psychiczną człowieka. Przez to etos staje się istotnym elementem życia duchowego i działania jednostki. Celem tego wychowania jest doprowadzenie do tego, aby wychowanek był zdolny przeżywać etos państwowy w najgłębszych treściach. Wiąże się to $\mathrm{z}$ takim działaniem wychowawczym, które prowadzi do uczuciowego przeżywania etosu pań-

\footnotetext{
36 Tamże, s. 59.

37 Tamże, s. 66-73.

38 Tamże, s. 171-173.
} 
stwowego. Zatem wychowanie powinno wywoływać miłość do państwa. Zasady obecne w etosie państwowym przez uczuciowe ich przeżywanie będą stawały się istotnym motywem działania. Przywiązanie do etosu nie wyklucza także krytycznego doń ustosunkowania się. Wychowanie, które stawia sobie za cel przygotowanie wychowanka do pełnego przeżywania etosu państwowego, zdaniem K. Sośnickiego, wytwarza strukturę psychiczną nazywaną usposobieniem lub sumieniem państwowym. Tej dyspozycyjnej stronie osobowości wychowanka odpowiadają przeżycia nazywane patriotyzmem państwowym ${ }^{39}$.

Zwykle, jak podkreśla K. Sośnicki, sumienie państwowe identyfikuje się z sumieniem moralnym. Na czym polega sumienie państwowe? W wyjaśnieniu tego aspektu odwołuje się do wypowiedzi Kerschensteinera i Förstera. Według Förstera to świadomość państwowa, która polega na tym, że człowiek umie godzić przeciwieństwa własnych idei z niezgodnymi ideami, interesami i dążenia na podstawie religijno-moralnej. Te wszystkie rozważania na temat etosu państwowego prowadzą Kerschensteinera i Förstera do wniosku, że świadomość państwowa powinna być podporządkowana sumieniu moralnemu ${ }^{40}$.

Po ustaleniu relacji między sumieniem państwowym a sumieniem moralnym autor analizuje treść wychowania państwowego. Treść tego wychowania powinny stanowić dwie kategorie cnót, czyli cnoty ogólnopaństwowe ważne w wychowaniu w każdym państwie oraz cnoty związane z funkcjonowaniem poszczególnych państw. Do pierwszej kategorii zalicza K. Sośnicki poczucie odpowiedzialności, zdyscyplinowanie dla państwa, wolę dla państwa, wolę dla praw, poczucie prawne, wierność dla narodu i ziemi ojczystej oraz obowiązek pracy kulturalnej. Do zakresu cnót specyficznych ważnych dla funkcjonowania w określonym państwie należą: jeśli państwo nastawione jest pokojowo wobec innych państw, to celem jego jest wyrabianie pacyfizmu, natomiast gdy państwo nastawione jest imperialistycznie, treścią wychowania państwowego będzie wszczepianie $\mathrm{w}$ nowe pokolenie nacjonalizmu albo w jeszcze bardziej skrajnej postaci szowinizmu ${ }^{41}$.

\footnotetext{
39 Tamże, s. 192-196.

40 Tamże, s. 196-238.

41 Tamże, s. 239-255
} 
Ostatnie lata przed II wojną światową wywoływały niepokoje związane ze wzrostem napięć na arenie międzynarodowej. Ponadto krytyka wychowania państwowego odsłoniła jego słabe punkty ${ }^{42}$. To spowodowało, że dostrzeżono potrzebę akcentowania $\mathrm{w}$ wychowaniu elementów narodowych. Stąd w wychowaniu państwowym pojawiają się ukierunkowania $\mathrm{ku}$ wychowaniu narodowemu.

\section{ODNIESIENIE DUCHOWIEŃSTWA KATOLICKIEGO DO WYCHOWANIA PAŃSTWOWEGO}

Propozycje zmian w szkolnictwie były śledzone przez środowisko katolickie na różnych etapach. Zwracano na to uwagę już $w$ fazie projektów zmian oświatowych. Wstępem do poważnych reform było powołanie przez Ministerstwo WRiOP w 1927 roku komisji do przygotowania projektu o ustroju szkolnictwa. Ta komisja wyniki swojej pracy ogłosiła w publikacji pt. Ustawa o ustroju szkolnictwa. Ten projekt został wydany w Warszawie w 1927 roku $^{43}$. Krytyczne omówienie tego projektu przedstawił na łamach „Ateneum Kapłańskiego” ks. Bolesław Kunka. Wskazał, że projekt uwypukla ujednolicenie ustroju szkolnego, podkreśla wagę kształcenia podstawowego obejmującego najszersze rzesze społeczne. Natomiast przez propozycje skrócenia nauki w gimnazjum do pięciu lat przyczynia się do obniżenia poziomu kształcenia w szkołach średnich ${ }^{44}$. Tym samym czytelników „Ateneum” uwrażliwił na projektowane zmiany.

Po przyjęciu ustawy Jędrzejewiczowskiej podnosiły się krytyczne głosy w środowisku nauczycieli chrześcijańskich. Pomimo że w ustawie wyeksponowano wychowanie religijno-moralne, to jednak obawiano się, że całe szkolnictwo zostanie podporządkowane sanacyjnej racji stanu ${ }^{45}$. Te obawy były wyrażane przez przedstawicieli Stowarzyszenia Chrześcijań-

${ }^{42}$ Por. B. Suchodolski, Wychowanie obywatelsko-państwowe, „Przegląd Pedagogiczny" 15 (1930) nr 20, s. 432-438.

${ }^{43}$ Ustawa o ustroju szkolnictwa. Projekt komisji powołanej przez ministra WRiOP wydany w Warszawie w 1927 r., Warszaw 1927.

${ }^{44}$ Por. B. Kunka, Organizacja szkolnictwa $w$ świetle rzadowego projektu, „Ateneum Kapłańskie” 21 (1928), s. 68-80.

${ }^{45}$ Nowy projekt ustroju szkolnictwa, „Nauczyciel Polski”, z 1 lutego 1932, nr 3. 
sko-Narodowego Nauczycielstwa Szkół Powszechnych ${ }^{46}$. To stowarzyszenie walczyło o chrześcijański obraz oświaty i życia społecznego ${ }^{47}$.

Stosunek Kościoła do wychowania państwowego został wyrażony w encyklice papieża Piusa XI Divini illius magistrii (O chrześcijańskim wychowaniu młodzieży $)^{48}$. Papież jasno zaakcentował, że Kościół respektuje prawo państwa do wychowania. Ale encyklika podkreśla też, że w dziele wychowania uczestniczą oprócz państwa także Kościół i rodzina. Wskazał też racje, na których opiera się prawo społeczności katolickiej do wychowania. Prawo Kościoła do wychowania religijnego wynika z macierzyństwa duchowego. Kościół przez chrzest rodzi nowe dzieci do życia nadprzyrodzonego. Stąd ma prawo do wychowania religijnego. Rodzina rodzi dzieci w porządku naturalnym. Jej aktywność wychowawcza jest niezbędna do wychowania dziecka, które w niej się narodziło. Państwo zaś ma prawo do wychowania $\mathrm{z}$ racji tego, że jest społecznością powołano do dbania o dobro wspólne.

$\mathrm{Na}$ temat wychowania państwowego wypowiedzieli się przedstawiciele Episkopatu Polski ustami kard. Augusta Hlonda ${ }^{49}$. Prymas Polski kard. A. Hlond przypomniał nauczanie Kościoła dotyczące państwa. On podkreślał, że Kościół respektuje zakres władzy państwowej. Oczekuje, że legalnie wybrana władza służyć będzie narodowi. Z perspektywy katolickiej chrześcijanie powinni uczestniczyć w życiu państwa, brać udział w polityce i troszczyć się o dobro wspólne.

Może żaden inny naród nie umie tak, jak my, ocenić ogromu dobrodziejstwa bożego, jakim jest własne Państwo. Przeżyliśmy przecież bezmiar klęski utraty bytu politycznego. Państwo zatem, które nam Opatrzność Boża przywróciła, powinno nie tylko pobudzać nas do niewygasającej w narodzie wdzięczności względem Stwórcy, lecz być także przedmiotem

${ }^{46}$ Por. W. Grabowska, Jędrzejewiczowska ustawa szkolna z 1932 r., s. 136.

47 Stowarzyszenie Chrześcijańsko-Narodowego Nauczycielstwa Szkół Powszechnych https://encyklopedia.pwn.pl/haslo/Stowarzyszenie-Chrzescijansko-NarodowegoNauczycielstwa-Szkol-Powszechnych;3980062.html (dostęp: 5.08.2019).

48 http://w2.vatican.va/content/pius-xi/la/encyclicals/documents/hf_p-xi_ enc_31121929_divini-illius-magistri.html (dostęp: 20.08.2019)

49 Por. kard. A. Hlond, O chrześcijańskie zasady życia społecznego, Gniezno 23.04.1932, https://sbc.org.pl/dlibra/docmetadata?showContent=true\&id=76181 (dostęp: 04.08.2019). 
uczuć tak głębokich i tak szczerej troski, iżbyśmy z nakazu sumienia i z potrzeby serca dbali o jego pomyślność, siłę i trwałość, ale nade wszystko o jego wysoką godność i etykę

Pomimo zasadniczej akceptacji dla państwa i wychowania do miłości ojczyzny pojawiły się krytyczne oceny projektu wychowania państwowego w środowisku teologicznym. Przedstawiciele Związku Zakładów Teologicznych publikowali je na łamach „Ateneum Kapłańskiego”. Dwa artykuły na ten temat opublikował tam ksiądz Jan Sicieński. Pierwszy artykuł ma charakter przeglądu koncepcji wychowania w państwach współczesnych ${ }^{51}$, a drugi odnosi się do wychowania państwowego w Polsce okresu międzywojennego ${ }^{52}$. Kilku autorów uwypuklało katolicki charakter wychowania oraz znaczenie nauczania religii katolickiej w trakcie wcielania w życie wychowania państwowego.

Ksiądz Jan Sicieński w pierwszym artykule opisuje dominujące tendencje w ówczesnej pedagogice. Zaznacza, że wychowanie jest kształtowane albo przez tendencje indywidualistyczne albo społeczne. Wychowanie eksponujące charakter społeczny zdominowane zostało przez pedagogikę eksperymentalną. Natomiast w cień usuwa się wychowanie, które uwzględnia etykę. Wartości i normy nie są obecne w pedagogice, a to skutkuje otwarciem się na liberalizm. Jego zdaniem, w miejsce etyki normatywnej rozwija się etykę indywidualistyczną. Na skutek panującego naturalizmu w koncepcjach wychowawczych w wychowaniu nie ma miejsca dla autorytetu i posłuszeństwa. Ostateczne źródło takiego podejścia tkwi w niewłaściwym poglądzie na naturę ludzką, wywodzącym się od J.J. Rousseau, który podkreślał, że człowiek ma w sobie wszystkie elementy potrzebne do swego rozwoju. Stąd zadaniem wychowania nie jest narzucanie czegokolwiek wychowankowi, ale raczej czuwanie, aby autonomia natury była respektowana $^{53}$. Jednak w człowieku, w jego naturze istnieje dysharmonia. Nie jest to tylko wynik nauczania średniowiecznego Kościoła, ale także starożytni

${ }^{50}$ Kard. A. Hlond, O chrześcijańskie zasady życia społecznego.

${ }_{51}$ Por. J. Sicieński, Wychowanie państwowe w świetle zasad nauki katolickiej, „Ateneum Kapłańskie” 1934, t. 34, z. 2, s. 113-130.

${ }_{52}$ Por. tenże, Wychowanie państwowe w świetle zasad nauki katolickiej, „Ateneum Kapłańskie” 1934, t. 34, z. 3, s. 267-290.

${ }^{53}$ Tenże, Wychowanie państwowe w świetle zasad, (z. 3), s. 116-117. 
dostrzegali ten brak harmonii, czego dowodem jest wg Sicieńskiego powiedzenie Eurypidesa „znamy cnotę, a oddajemy się występkowi”"54.

Przeciwieństwem wychowania idealistycznego jest wychowanie społeczne zdobywające coraz szersze znaczenie w tamtym czasie. Ono, jak powie Siecieński, „wysunąwszy na czoło zagadnienia społeczne, a właściwie państwowe, ubezwartościowił on jednostkę, poświęcając ją bezapelacyjnie ogółowi”"55.

Dla popularyzacji wychowania społecznego, a zwłaszcza państwowego, istotne znaczenie miały, zdaniem Sicieńskiego, poglądy Hegla. Poglądy Hegla inspirowały do tego, że zrodził się, jak ujmuje to Sicieński, nurt realizmu, który w wychowaniu przybierał zabarwienie naturalistyczne. Ten realizm spotykamy zarówno w kapitalizmie, jak i marksizmie jako reakcje na przesadny idealizm. Ten realizm zdobywa też coraz większy wpływ na wychowanie. Stąd ówczesne koncepcje wychowania państwowego są syntezą idealizmu zaczerpniętego z koncepcji Hegla, socjalizmu $\mathrm{z}$ jego naturalistyczną negacją wyższego porządku ${ }^{56}$.

Autor pragnie podkreślić chrześcijańskie spojrzenie na wychowanie państwowe. Dlatego przedstawia argumentację często odwołującą się do nauczania Kościoła, a zwłaszcza do encykliki papieża Piusa XI O chrześcijańskim wychowaniu młodzieży. Człowiek dopiero w społeczeństwie może prowadzić życie w pełni ludzkie, ale w tym nie wyczerpuje się pełnia jego życia. Człowiek nie ogranicza się tylko do życia w społeczeństwie. Jego osobiste powołanie przekracza zakres życia społecznego i wykracza ponad to. Osoba ludzka ma instynkt samozachowawczy i w pewnym miejscu styka się z instynktem społecznym. Tym tłumaczy się naturalna siła poświęcenia wielu jednostek dla państwa. Wychowanie państwowe buduje na instynkcie społecznym. Dlatego w tym celu rozbudza się cnoty społeczne. Pierwszą z tych cnót jest poświęcenie się dla dobra społecznego. Bez rozwinięcia tej cnoty poświęcenia dla dobra społecznego można wychować konsumentów wartości materialnych i duchowych oferowanych przez państwo, a nie świadomych współtwórców własnego państwa ${ }^{57}$.

\footnotetext{
${ }^{54}$ Tamże, s. 117.

55 Tamże, s. 119.

56 Tamże, s. 120.

57 Tamże, s. $120-122$.
} 
Właściwie ukształtowanie wychowania państwowego wymaga zrozumienia, czym jest państwo. Często państwo jest rozumiane jako pewien organizm, gdzie całość ma pierwszeństwo przed poszczególnymi członkami. Tymczasem z punktu chrześcijańskiego nie jest ono organizmem, lecz organizacją, której celem jest dążenie dla dobra obywateli. Państwo jest najwyższą organizacją obejmującą swym wpływem wszystkich obywateli, którego kompetencją jest kształt zagadnień doczesnych. Władza państwowa jest dana przez Boga, a sam ustrój zaś jest wynikiem władzy ludu ${ }^{58}$.

Następnie autor rozpatruje, jaka jest relacja jednostki do państwa i państwa do jednostki. Zauważa, że fundament państwa znajduje się w naturze ludzkiej, a naturalną potrzebą człowieka jest łączenie się, stąd jednostka stanowi rację istnienia państwa. Państwo w stosunku do jednostki ma istnienie pochodne. Ze względu na przeznaczenie jednostka przewyższa państwo. Państwo ma zadania doczesne, a jednostka zadania wieczne. Wobec tego państwo jest dla jednostki, bez względu na ich potrzeby doczesne. Odwrócenie tego porządku, zdaniem Sicieńskiego, prowadzi do absurdu ${ }^{59}$. Jednostka przewyższa państwo przeznaczeniem wiecznym, swoim powołaniem nadprzyrodzonym do życia w wieczności. Naczelnym obowiązkiem jednostki jest spełnić swoje przeznaczenie wieczne. Dlatego pomocą w spełnianiu tego przeznaczenia jest jego rodzina a także w pewnym zakresie państwo. Dopiero w ramach państwa istnieje dla jednostki możliwość zdobycia względnej szczęśliwości doczesnej. Im lepiej państwo zaspokaja jej potrzeby, tym większa jest jego siła przyciągająca $^{60}$.

Sicieński zauważa także, że każda jednostka, ale również naród oprócz pragnień ogólnoludzkich ma też pragnienia własne, dlatego głodu duszy ludzkiej nie jest w stanie zaspokoić jakiekolwiek państwo, ale może to uczynić tylko państwo własne. Sicieński powołuje się tu na doświadczenie płynące z niewoli narodowej. „Dawał zaborca dobrobyt, dawał nam, nawet na niektórych odcinkach, dość szeroką cywilizację, ale nie potrafił zaspokoić pragnienia polskiej duszy, która instynktownie szukała wła-

\footnotetext{
58 Tamże, s. 126-127.

59 Tamże, s. 128.

60 Tamże, s. 128-129.
} 
snego gniazda, własnej państwowości”' ${ }^{1}$. Dopiero własne państwo może zrozumieć i zaspokoić najgłębsze potrzeby. $\mathrm{Z}$ tych potrzeb ukształtowała się przeszłość, czyli historia, literatura, obyczaje, kultura i ustrój społeczny. Zatem wychowanie państwowe zależne od potrzeb jednostek powinno dbać przede wszystkim o duchowy rozwój jednostek ${ }^{62}$.

W drugim części artykułu Sicieński podkreśla niebezpieczeństwa wychowania państwowego, które traktuje jednostkę jako całkowicie podporządkowaną państwu. Powołuje się tu z jednej strony na wypowiedzi przedstawicieli hitlerowskich Niemiec, a z drugiej strony Rosji Sowieckiej. Wyprowadza stąd wnioski wskazujące, że w takim rozumieniu wychowania osoba ludzka nie ma praw i gdy przestaje w jakimś momencie być potrzebna, ląduje na śmietniku historii.

Należy zauważyć, że ks. Jan Siecieński dobrze orientował się w nurtach ówczesnej pedagogiki, znał także katolicką wizję wychowania inspirowaną encykliką papieża Piusa XI Divini illius magistri oraz publikacje polskie i zagraniczne podejmujące problematykę wychowania państwowego. Szczególne podkreślić należy, że nie tylko znał wiele publikacji na temat wychowania państwowego, lecz także je krytycznie oceniał. Na uwage zasługuje jego polemika z zasadniczymi tezami Kazimierza Sośnickiego zawartymi w jego książce habilitacyjnej pt. Podstawy wychowania państwowego. Z punktu widzenia katolickiego ukazał słabe punkty koncepcji Kazimierza Sośnickiego. Szczególnie uwypuklił to, że etos państwowy nie może dominować nad etosem moralnym. Wychowanie w duchu etosu państwowego, które odwołuje się do nakazów czy zakazów prawa, nie kształtuje od wewnątrz człowieka i dlatego rezultaty takiego wychowania nie mogą być trwałe.

Realizacja wychowania państwowego, mimo zapisu o dopuszczeniu nauczania religii katolickiej w szkołach państwowych rodziła różne trudności. Te trudności były dostrzegane i na nie reagowali piszący na łamach „Ateneum Kapłańskiego”. Na przełomie lat 20. i 30. zdarzało się, że likwidowano etaty nauczycieli religii, zwalniano lub czyniono trudności w zatrudnieniu księży prefektów bez zgody Ordynariusza, redukowano liczbę godzin religii katolickiej, zmniejszano pensje księży prefektów,

\footnotetext{
${ }_{61}$ Tamże, s. 129.

62 Tamże, s. 129-130.
} 
powierzano prowadzenie lekcji religii nauczycielom świeckim bez wymaganej misji kanonicznej wystawianej przez miejscowego ordynariusza ${ }^{63}$.

Te zachowania wywoływały reakcje między innymi H. Kaczorowskiego, S. Biskupskiego S. Wyszyńskiego. Wychodzono z założenia, że wychowanie realizowane w szkołach musiało realizować również postanowienia konkordatu. Na jego mocy nauka religii dla uczniów katolików jest obowiązkowa. Szczegółowe uregulowania prawne nauki religii w szkole zawierało Rozporządzenie Ministra Wyznań Religijnych i Oświecenia Publicznego z 9 grudnia 1926 roku o nauce szkolnej religii katolickiej ${ }^{64}$. W tym rozporządzeniu znalazło się określenie, że młodzież szkolna jest obowiązana brać udział w praktykach religijnych i należą one do całości nauczania i wychowania religijnego. Do praktyk religijnych należały: udział w niedzielę i święta oraz na początku i końcu roku we Mszy świętej, coroczne trzydniowe rekolekcje, trzy razy w roku wspólna spowiedź i Komunia święta oraz wspólna modlitwa przed i po lekcjach ${ }^{65}$. Praktyki religijne były szczególnie mocno krytykowane w tamtym czasie przez nauczycieli o lewicowych poglądach. Przeciwnicy takich praktyk podkreślali, że to mogło z jednej strony generować wśród młodzieży fałsz i obłudę. Praktyki młodzieży obarczały też nauczycieli dodatkowymi obowiązkami w dniu wolnym od pracy, jakim była niedziela. Stąd K. Kaczorowski starał się wyjaśnić potrzebę uczestniczenia w tych praktykach. Najpierw podkreślił, że nie jest to przymus, lecz obwiązek. Przymus kojarzy się zwykle z zewnętrzną koniecznością. W odniesieniu do praktyk religijnych mamy do czynienia nie z przymusem lecz z obowiązkiem. Jest to obowiązek moralny. Wartości zinterioryzowane $\mathrm{w}$ sumieniu stają się wewnętrznym imperatywem do ich podjęcia. Sam więc wychowanek realizuje je $\mathrm{z}$ własnego przekonania. Tymczasem często uczeń jest jeszcze na tyle niedojrzały, że nie potrafi dokonać interioryzacji wartości religijnych. Potrzebuje nauczyciela, który pomoże mu odkryć prawdę poprzez przedstawienie głębokiej motywacji pozostającej w zgodzie $\mathrm{z}$ autonomią jednostki ${ }^{66}$.

${ }^{63}$ J. Szczepaniak, Episkopat w obronie katolickiego charakteru polskiej szkoły 1927-1937, Kraków 2000, s. 146-147; 182-217.

${ }^{64}$ Dz.U. 1926 nr 2 poz. 24/24 s/ 51-52.

65 Tamże, s. 52.

${ }^{66}$ H. Kaczorowski, O praktyki religijne młodzieży szkolnej, „Ateneum Kapłańskie” 20 (1927) nr 5, s. 478-479. 
Przedmiotem kontrowersji stał się również wstęp ustawy, mówiący o „wyrobieniu religijnym, moralnym, umysłowym i fizycznym” jako celach wychowania. Zamiast o wychowaniu mówiono o wyrobieniu. To zdaniem Wyszyńskiego było niekorzystne z katolickiego punktu widzenia, ponieważ osobno potraktowano wyrobienia religijne i moralne. $\mathrm{Z}$ takiego ujęcia można było wywnioskować o istnieniu innej, niezależnej świeckiej etyki. Wyszyński za właściwszą uznał więc formułę „wychowania religijno-moralnego" ${ }^{67}$. Z kolei S. Biskupski zwracał uwagę na bezprawny charakter zachowań administracji szkolnej wobec problemów w nauczaniu religii. Odpowiedzialną za ów stan rzeczy czynił administrację szkolną niższej instancji ${ }^{68}$.

Wyszyński krytykował także ustawę o szkołach prywatnych dającą władzy państwowej możliwość pełnej kontroli. To dawało możliwość kontroli także do szkół katolickich. Takie rozwiązanie było sprzeczne z nauczaniem Divini illius magistri o harmonijnym współdziałaniu wszystkich podmiotów uczestniczących w procesie wychowania. Przerost uprawnień państwa burzył tę równowagę $\mathrm{w}$ procesie wychowania. Wyszyński dostrzegał dążenie państwa do monopolizowania oświaty i był przekonany, że należy uznać za szkodliwą taką tendencję w wypowiedziach tej ustawy o szkołach prywatnych ${ }^{69}$.

\section{ZAKOŃCZENIE}

Środowisko teologów katolickich w Polsce w okresie 1920-1939 aktywnie uczestniczyło w przemianach dokonujących się w Polsce okresu międzywojennego. Była to przede wszystkim aktywność intelektualna przejawiająca się w licznych publikacjach naukowych. Oprócz problematyki teologicznej podejmowało też krytyczną refleksję odnoszącą się do koncepcji wychowania w Rzeczypospolitej. Zarówno biskupi, jak i katoliccy duchowni mieli orientację $\mathrm{w}$ dokonujących się przemianach i koncepcjach

${ }^{67}$ S. Wyszyński, Z ostatnich walk o religijny charakter szkoły polskiej, „Ateneum Kapłańskie" 30 (1932), s. 55-56, s. 55-56.

${ }^{68}$ S. Biskupski, Prawne nieporozumienia $w$ związku z nauczaniem religii $w$ szkole, „Ateneum Kapłańskie” 36 (1935), s. 381-386.

${ }^{69}$ S. Wyszyński, Z ostatnich walk o religijny charakter szkoły polskiej, s. 57-59. 
wychowania. Uwagę środowiska katolickiego przyciągały zarówno projekty przewidywanych reform oświatowych, jak również przyjęte już konkretne rozwiązania prawne $\mathrm{w}$ postaci ustaw sejmowych. Teologowie katoliccy uważnie śledzili również publikacje pedagogiczne zarówno zagraniczne, jak i polskie dotyczących tego zagadnienia. Widziano potrzebę takiego wychowania, które mobilizuje do troski o własne państwo i zaangażowania się w jego rozwój, ale też zdawano sobie sprawę, że nie powinno rezygnować $\mathrm{z}$ wartości ważnych dla narodu żyjącego w państwie. Podejmowano także obronę katolickiego elementów wychowania w szkole publicznej.

\section{BIBLIOGRAFIA}

Arnold S., Teoretyczne podstawy nauki o Polsce współczesnej, „Zrąb” 1930, nr 3, s. 334-347. Balicki Z., Egoizm narodowy wobec etyki, Lwów 1903.

Balicki Z., Zasady wychowania narodowego, Warszawa 1909.

Bartnicka K., Wychowanie państwowe: do dyskusji nad problemami ideologii wychowawczej sanacji, „Rozprawy z Dziejów Wychowania” 12 (1972), s. 61-72.

Biskupski S., Prawne nieporozumienia $w$ zwiazku z nauczaniem religii w szkole, „Ateneum Kapłańskie" 36/4 (1935), s. 381-387.

Czerwiński S., O nowy ideał wychowawczy, Warszawa 1934.

Dyczewski L., Rodzina twórca i przekazicielem kultury, Lublin 2003.

Grabowska W., Jędrzejewiczowska ustawa szkolna z 1932 r., „Rozprawy z Dziejów Oświaty" 12 (1969) s. 123-141.

Hlond A., O chrześcijańskie zasady życia społecznego, Gniezno 23.04.1932, https://sbc. org.pl/dlibra/docmetadata?showContent=true\&id=76181 (dostęp: 04.08.2019).

Jędrzejewicz J., Wychowanie państwowe, „Zrąb” 1930, nr 3. s. 311-320.

Kunka B., Organizacja szkolnictwa w świetle rządowego projektu, „Ateneum Kapłańskie” 21 (1928) s. 68-80.

Mysłakowski Z., Wychowanie państwowe a narodowe, Lwów-Warszawa 1931.

Panenkowa I., Wychowanie państwowe czy narodowe, Warszawa 1930.

Patkowski A., Poznanie własnej ziemi jako podstawa wychowania obywatelskiego, „Zrąb”1930 nr 3 s. 370-377.

Suchodolski B., Wychowanie obywatelsko-państwowe, „Przegląd Pedagogiczny” 15 (1930), nr 20, s. 432-438.

Sicieński J., Wychowanie państwowe w świetle zasad nauki katolickiej, „Ateneum Kapłańskie" 1934, t. 34, z. 2, s. 113-130.

Sicieński J., Wychowanie państwowe w świetle zasad nauki katolickiej, „Ateneum Kapłańskie" 1934, t. 34 z. 3, s. 267-290.

Skoczylas K., Związek Zakładów Teologicznych im św. Jana Kantego w Polsce, „Studia Włocławskie" 20 (2018), s. 25-42. 
Sobczak J., Przykłady formułowania ideału Obywatela-Patrioty na tle istotnych dla narodu polskiego wydarzeń polityczno-społecznych, „Studia Pedagogiczne” 1980, z. 6, s. 9-56.

Sośnicki K., Podstawy wychowania państwowego, Lwów-Warszawa, 1936.

Stolarczyk M., Wychowanie państwowe w Drugiej Rzeczypospolitej w świetle programów szkolnych (po wprowadzeniu reformy oświatowej z 1932 roku, „Lubelski Rocznik Pedagogiczny" 37 (2018), z. 3, s. 215-235.

Szczepanowski S., Myśli o odrodzeniu narodowym, Lwów-Warszawa 1923.

Szczepanowski S., O polskich tradycjach wychowawczych, Lwów 1912.

Szepietowski M., Naród i wychowanie w myśli Romana Dmowskiego, „Niepodległość i Pamięć” 12 (2005) nr 1, s. 149-152.

Topij-Stempińska B., Kaźmierczak P., Wychowanie narodowe a wychowanie państwowe, „Horyzonty Wychowania” 7 (2008) nr 14, s. 225-239.

Ustawa z dnia 11 marca 1932 roku o ustroju szkolnictwa, Dz.U. 1932 Nr 38, poz. 398, art. 5-12

Wałek Czarnecki T., Kultura klasyczna a wychowanie państwowe, „Zręb” 1930, nr 3, s. 348-359.

Wyszyński S., Z ostatnich walk o religijny charakter szkoły polskiej, „Ateneum Kapłańskie” 30 (1932), s. 55-59.

Zarzecki L., Wychowanie narodowe, Warszawa 1929.

Ziemnowicz M., Wychowanie państwowe w szkole, „Przegląd Pedagogiczny” 1931, nr 15-16, s. 13-23.

Ziemnowicz M., Rodzina a wychowanie państwowe, Warszawa-Lwów 1932. 